\title{
INTERNALISASI KEBIJAKAN PEMERINTAH ACEH BERDASARKAN UNDANG - UNDANG NOMOR 11 TAHUN 2006 TENTANG PEMERINTAH ACEH
}

\author{
Nellis Mardhiah ${ }^{1}$, Rahma Hidayati ${ }^{2}$, Mursyidin ${ }^{3}$ \\ ${ }^{1}$ Fakultas Ilmu Sosial dan Ilmu Politik, Universitas Teuku Umar \\ email: nellismardhiah@utu.ac.id \\ ${ }^{2}$ Fakultas Ilmu Sosial dan Ilmu Politik, Universitas Teuku Umar \\ email: rahmahidayati@utu.ac.id \\ ${ }^{3}$ Fakultas Ilmu Sosial dan Ilmu Politik, Universitas Teuku Umar \\ email: mursyidin@utu.ac.id
}

\begin{abstract}
law number 11 Year 2006 was the implementation of the contents of the notes kesefahaman a memorandum of understanding (MoU) to Helsinki Government Indonesia with the free Aceh Movement (GAM) on 15 August 2005. This MOU is the beginning of a permanent peace in Aceh. Objective of writing this was the development of the implementation of the BAL after peace in Aceh. This research with qualitative and descriptive analysis method, by using the technique of observes and interviews. The goal of his research can contribute to the legislature in order to understand the stages of the process of legislation happen polemic in the realization of this legislation as BAL due to rules of normative binding, but in terms of the realization of the implementation of the special autonomy policy is not as easy as normative rules contained in regulation perundangan-undangan. It is given the legal system in Aceh. The policy objectives have not yet reached target BAL of the Aceh government readiness in meeting the needs of the community. In addition, the implementation of this legislation requires specific strategies and the DPRA capacity is crucial in separating political and administrative functions for the achievement of the input, output and outcomes in public life in post peace in Aceh.
\end{abstract}

Keywords: Development Of The BAL. DPRA. Aceh Peace 


\section{PENDAHULUAN}

Aceh merupakan salah satu provinsi yang mempunyai karakter tersendiri dibandingkan dengan daerah-daerah lain di Indonesia. Selain mendapatkan sebutan sebagai "Daerah Modal" bagi Republik Indonesia (RI), yang diisytiharkan oleh Presiden Soekarno pada 4 September 1959 di Meulaboh, Aceh Barat (Alfian, 2006) pengisytiharan Aceh sebagai daerah modal bagi RI berikutan penyerahan dua pesawat terbang kepada Pemerintah Indonesia pada bulan agustus 1948, kemudian kedua pesawat terbang tersebut menjadi asal daripada Garuda Indonesian Airways. Di samping itu pula, pada tahun 1949 rakyat Aceh turut menyumbangkan anggaran oprasional pemerintah Indonesia dalam rangkah $b$ pengembalian status pemerintah pusat ke wilayah yogyakarta.

Kendatipun demikian tuntutan rakyat aceh juga dapat terlihat ingin mendapatkan keadilan dalam perwujudan peraturan syariat Islam. Akibat daripada ketidakadilan pemerintah pusat tersebut, telah menunjukkan rasa tidak puas hati rakyat terhadap kebijakan pemerintah pusat. Maka pada tanggal 21 Disember 1953 di Aceh diwujudkan sebuah kelompok perlawanan yang dikenal dengan pemberontakan Darul Islam/Tentara Islam Indonesia (DI/TII) yang dipimpin oleh Teungku Muhammad Daud Beureueh.

Pemberontakan DI/TII yang dipimpin oleh Teungku Daud Muhammad Daud Beureu'eh tersebut sebagai perlawanan bagi memperjuangkan nasib rakyat Aceh dalam memperjuangkan keistimewaan bagi rakyat Aceh dapat melaksanakan syariat Islam sebagaimana yang telah dijanjikan oleh pemerintah pusat. Serta ingin memberikan kritikan terhadap kebijakan pemerintah pusat yang tidak adil bagi rakyat Aceh. Perjuangan DI/TII di Aceh berakhir pada tahun 1959. Dalam penyelesaian itu, DI/TII tidak dianggap sebagai pihak yang kalah dan Aceh diberikan kedudukan wilayah otonomi dengan status Provinsi Daerah Istimewa Aceh. Adapun keistimewaan yang diperoleh Aceh adalah bidang agama, adat dan pendidikan. Status wilayah otonomi ini bagi Aceh tersebut ditetapkan berdasarkan undang-undang Nomor 18 Tahun 1965 tentang Pemerintah Daerah. Rancangan undang-undang tentang syariat Islam yang diusulkan oleh parlimen Aceh pada masa itu tidak pernah mendapatkan kelulusan oleh pemerintah pusat.

Pemerintah pada era orde lama telah usia terjadi kembali pertentangan antara rakyat Aceh dengan pemerintah Indonesia hingga pada orde baru yang dipimpin oleh Presiden Soeharto. Pada masa itu pemerintah pusat gagal mengawal keseimbangan pengelolaan kekayaan antara pemerintah pusat dengan rakyat. Pendekatan kekerasan dan tekanan ekonomi yang dilakukan oleh pemerintah pusat yang menyebabkan rakyat aceh memberikan dukungan kepada gerakan pemberontak (Richard, 1996). Penentangan rakyat Aceh terhadap pemerintah pusat, hal ini disebabkan kerana pengekangan terhadap pelaksanaan syariat Islam, eksploitasi besarbesaran terhadap hasil alam Aceh, yang tidak mempedulikan nasib rakyat aceh melalui separatis pemberontak dikenal dengan Gerakan Aceh Merdeka atau GAM .

GAM ditubuhkan oleh Teungku Hasan Muhammad di Tiro pada 4 Desember 1976, yang bertujuan untuk memperjuangkan kemerdekaan bagi aceh, kerana disebabkan oleh sikap tidak adil pemerintah pusat dalam membangun daerah, terutama bagi pembangunan daerah aceh. Rakyat aceh merasa dikhianati oleh pemerintah pusat, aceh mempunyai sumber alam yang berlimpah. Tetapi hasil sumber alam tersebut tidak turut dinikmati oleh rakyat aceh yang sebahagian besar hidup dalam kemiskinan.

GAM berjuang bagi kemerdekaan aceh semenjak 4 Desember 1976 sehingga 14 agustus 2005 dua strategi utama. Pertama, strategi perang gerila gampong dan strategi perang gerila kota. Adapun strategi gerila gampong ialah strategi mewujudkan keyakinan terhadap masyarakat bahawa perjuangan GAM merupakan suatu perjuangan untuk aceh menjadi sebuah negara merdeka. Dengan demikian, strategi politik tersebut GAM telah telah memperoleh berbagai keberhasilan. Seperti dari segi diplomasi, pengasas GAM Teungku Hasan di Tiro pada 12 June 1990 dengan membawa permasalahan GAM kepada PBB atau Perserikatan BangsaBangsa. 
Sebelum pihak GAM dan Pemerintah Indonesia memateraikan MoU Helsinki, Finland pada 15 agustus 2005 penyelesaian konflik politik antara GAM dengan Pemerintah Indonesia secara berterusan telah dilakukan beberapa fase kepemimpinan Pemerintah Indonesia, mulai pemerintah Indonesia mulai dari fasa Soeharto sehingga pemerintah Indonesia di bawah Presiden Sosilo Bambang Yudhoyono. Sempada dengan mengguna pakai pendekatan diplomasi atau dialog. Pada 27 Januari 2000 yang mewakili Indonesia di Geneva (Switzerland) Hasan Wirayuda telah bertemu dengan wakil GAM Sweden Teungku Zaini Abdullah untuk menerusi satu perundingan yang difasilitasi oleh Henry Dunant Centre (HDC), insiasi kedua belah pihak bersedia untuk bertemu di Bavois (Switzerland). Pertemuan antara wakil GAM tersebut telah menghasilkan Bavois Agreement (Hamid, 2006).

Pelaksanaan jeda kemanusiaan disambut gembira oleh rakyat aceh, yang begitu lama ingin merasakan suasana aman yang terhindar daripada konflik di aceh yang berterusan di aceh. pihak Pemerintah Indonesia dan GAM diharapkan dapat menahan diri untuk tidak mengguna pakai pendekatan ketenteraan dan kekerasan ketenteraan dalam menyelesaikan konflik politik di aceh. Negara Amerika Serika, European Union $(E U)$ menyambut baik tentang jeda kemanusiaan di Aceh. sementara pihak United States Agency For International Development (USAID), pemerintah Inggris, pemerintah Norway dan pemerintah New Zealand bersedia memberikan bantuan oprasional antar bangsa untuk memantau pelaksanaan jeda kemanusiaan tersebut. Bencana tsunami di Aceh pada 26 Desember 2004, telah menjadi pencetus kepada berlaku perdamaian antara GAM dengan pemerintah Indonesia. Kesepakatan perdamaian antara kedua belah pihak terwujud melalui pemeteraian MoU di Helsinki.

Pemerintah RI dan GAM menegaskan komitmen mereka untuk penyelesaian konflik Aceh secara damai, menyeluruh, berkelanjutan dan bermartabat bagi semua. Para pihak bertekad untuk menciptakan kondisi sehingga pemerintahan aceh dapat mewujudkan melalui suatu proses yang demokratis dan adil dalam NKRI. Para pihak sangat yakin bahawa dengan penyelenggaraan damai atas konflik tersebut akan memungkinkan pembangunan kembali Aceh pasca tsunami pada 24 Desember 2004 dapat mencapai kemajuan dan keberhasilan. Nota kesefahaman ini merinci isi persetujuan yang dicapai dengan prinsip-prinsip yang akan memandukan proses transformasi. Pada 5 Juli 2006 yang diwakili oleh 10 (sepuluh) franks DPRA (Dewan Perwakilan Rakyat Aceh). rancangan undang-undang ini yang terdiri dari 40 bab dan 273 pasal. Ini momentum awal Aceh bisa memulai pembangunan dan melupakan masa konflik pada masa silam.

Undang-Undang Pemerintah Aceh di singkatkan dengan UUPA adalah undang-undang tahun 2006 tentang penyelenggaraan pemerintahan Aceh, perwujudan naskah ini tertulis dalam MoU Helsinki. Pernyataan tersebut diamanatkan pada 31 Mareh 2006.. Wilayah Aceh meskipun demikian setelah lahir UUPA telah mengundang banyak protes dari kalangan yang mengatas namakan rakyat. Dalam pelaksanaan UUPA harus dijalankan sesuai dengan kaedah yang berlaku supaya dapat mewujudkan perdamaian di Aceh. Maka ingin melihat perkembangan pelaksanaan kebijakan UUPA pasca perdamaian Aceh. Oleh sebab itu menjadikan tumpuan peranan perlembagaan legislatif dan eksekutif harus menjalankan tugas dan kewajiban sesuai dengan peraturan perundangan-undangan yang berlaku.

\section{TINJAUAN PUSTAKA}

Dalam Dye atau Shfritz and Russel dianggap terlalu sederhana serta tidak cukup menggambarkan keseluruhan konseptualisasi public policy, beranjak dari kelemahan tersebut menurut pandangan Anderson, public policy pada lazimnya merupakan serangkaian tindakan terarah yang dilakukan oleh aktor atau sejumlah aktor menangani masalah-masalah tertentu (Mahmud, 1995 : 6). Menurut Yusuf (2011) dalam hasil kajian nya menjelaskan penyelesaian konflik politik antara pemerintah Indonesia dengan GAM yang berterusan di Aceh dapat pula diselesaikan selepas berlakunya bencana tsunami di aceh. ialah penyelesaian konflik politik 
yang berhujung pada pematerian MoU Helsinki, Finland pada tanggal 15 agustus 2005, MoU Helsinki mempunyai impak besar bagi kehidupan rakyat aceh.

Namun tidak terlepas halnya situasi konflik demikian dinyatakan (Mahmud, 1995:4) bahawa pelaksanaan kebijakan pada lazimnya kebijakan terlahir dari keputusan pemerintah yang bersifat mengikat. Dekimian hal nya yang disampaikan oleh Widodo (2007) bahwa keputusan yang diambil pemerintah sebagai penjabaran dari fungsi yang melekat. Secara fundamental, fungsi tersebut merangkumi 2 (dua) kategori namun tidak dapat dipisahkan (two distinct function of government) berupa fungsi politik dan fungsi Administratif. Pernyataan demikian senada juga dalam model implemetasi yang disampaikan oleh Edwar III (1984:1) bahwa tanpa implementasi yang efektif maka keputusan pembuat kebijakan tidak berhasil dilaksanakan. Implementasi adalah kebijakan aktiviti yang kelihatan setelah dikeluarkan pengarahan yang sah dari suatu kebijakan yang meliputi upaya mengurus input untuk menjadi output atau outcome.

Menurut (dalam Sautma.2009) dalam hasil penelitian nya hubungan kekuasaan pemerintah pusat dan daerah sama seperti daerah otonom lainnya. Hanya saja membedakan hanya aspek kedudukan wilayah otonomi khusus telah ditetapkan secara normatif dalam UUPA. Anatomi ideal dalam kerangka di atas memberikan kabsahan sebagai falsafah dan sosiologis dibentuk undang-undang tentang Pemerintah Aceh. UUPA ini menetapkan dengan tegas bahawa Pemerintah Aceh merupakan bahagian yang tidak terpisah dari NKRI. Dengan demikian, otonomi seluas-luasnya pada lazimnya bukanlah sekadar hak, tetapi lebih dari yang merupakan kewajiban konstitusional untuk dimanfaatkan sebesar-besarnya bagi kesejahteraan di aceh.

Thomas Dye dalam karya nya "Understanding public policy" menggambarkan kebijakan pemerintah sebagai "apa pun yang dipilih untuk dilakukan dan tidak dilakukan pemerintah" (anything a government chooses to do or nor todo).(Mahmud, 1995). Dye Shifrtz and Russel dalam (Pasolong, 2008: 29) menyatakan kebijakan pemerintah sebagai " apa pun yang diputuskan untuk dilakukan dan tidak dilakukan oleh pemerintah" (whatever government decides to do or not to do). Demikian halnya dengan UUPA telah di putus sebagai aturan yang mengikat dalam pelaksanaan kebijakan pemerintah aceh.

Sholikin (2006) menjelaskan nota kesefahaman merupakan komitmen pemerintah pusat dan GAM untuk mengakhiri kontak senjata yang sudah terjadi sejak tahun 1976. Akar perlakuan tidak adil secara politik, ekonomi, budaya pemerintah oleh pemerintah pusat Indonesia. Keputusan yang diambil pemerintah pusat sebagai penjabaran dan fungsi yang melekat secara pada dan tak terhindarkan harus dilakukan oleh pemerintah. Secara fundamental harus dilaksanakan secara tidak terpisah iaitu, fungsi politik dan fungsi adiministratif. (Widodo, 2007 :15). Fungsi politik pemerintah berkaitan dengan pembuatan kebijakan (public policy making) atau pernyataan apa yang menjadi keinginan pemerintah.

Sedangkan fungsi adiministratif berkaitan dengan pelaksanaan kebijakan, apabila dalam kondisi kedudukan UUPA secara implisit aturan realisasi pelaksanaan nya berasal dari undangundang Nomor 18 Tahun 2001 tentang autonomi khusus, namun hal ini menunjukkan peraturan yang khusus dapat menyampingkan peraturan yang umum. Tahapan implementasi kebijakan pada posisinya yang berbeda, namun pada prinsipnya setiap kebijakan pemerintah kepada masyarakat senantiasa di tindak lanjut dengan implementasi kebijakan, kerana implementasi dianggap sebagai wujud utama dalam tahap yang menentukan dalam proses kebijakan (Birklan, 2001:177).

Implementasi UUPA belum optimal dari observers sementara, menurut Mawardi Ismail Akademis Fakulti Undang-undang UNSYIAH bahawa implementasi UUPA menjadi salah satu polemik, padahal dalam UUPA bermula tata kelola pemerintah, perdagangan dan ekonomi, pendidikan dan pertahanan, kelautan dan investasi hingga hak asasi manusia yang di tindak lanjut dengan disahkan UUPA. Pemerintah Pusat masih sangat represif terhadap pelaksanaan 
realisasi UUPA tantangan yang dihadapi oleh pemerintah Indonesia adanya dualisme kebijakan undang-undang di Aceh, di mana UUPA harus mengikuti perundangan yang lain di wilayah Negara Kesatuan Republik Indonesia. Menurut (asra ,2010) pemerintah pusat mesti membuat bentuk produk undang-undang agar dalam menyusun norma, secara opreasinal dan prosedur sehingga benar-benar tidak mengurangi kuasa yang dimiliki oleh Pemerintah Aceh. Menurut (Zulfikar, 2011) Implementasi UUPA terkait dengan permasalahan persekitaran, pemerintah dinilai sangat diskriminatif, kerana lebih cenderung terlibat dalam permasalahan politik, padahal dalam konteks UUPA menyebutkan memiliki kuasa khusus dalam perencanaan implementasi pemanfaatan dan pengawasan terhadap sumber daya alam dengan prinsip keterbukaan dalam pembangunan yang berkelanjutan.

Hasil tim pemantauan dari DPR-RI memperjelaskan undang-undang iaitu: UU Nomor 18 Tahun 2001 dan hasil kesepakatan antara Pemerintah Indonesia dan GAM yang dikenal dengan MoU Helsinki. Dan UUPA. Akan tetapi UUPA tersebut memberikan banyak peluang untuk pembangunan Aceh namun dalam implementasi nya belum optimal untuk kemakmuran Aceh. Menurut Rahmawati (2007) menjelaskan adanya skeptis sekali gus harapan atas implementasi UUPA sikap ini disebabkan diragukan komitmen department-departemen di Pemerintah Pusat dalam membuat peraturan yang mendukung UUPA cenderung paradigma centralistic dan berorientasi jabatan sehingga dapat menghambat implementasi UUPA. serta Trijono (2009) menyatakan implementasi belum efektif memerlukan strategi khusus untuk mengatasinya, dalam proses yang dilakukan melalui kapasiti perlembagaan, kebijakan dan strategi pemeliharaan dan pencegahan konflik.

Hal yang demikian apa yang telah disampaikan beberapa hasil penelitian dan pengamantan yang telah dilakukan dapat menggambarkan bahwa jeduudkan UUPA belum mencapai tujuan yang telah ditetapkan. Kaitannya dengan DPRA sebagai esensi penyelenggaraan pemerintahan di Aceh, akan tetapi harus menyesuaikan dengan peranan dan fungsinya diselaraskan dari pada implementasi kebijakan baik dari segi adiministratif mahupun politik sesuai dengan aspirasi rakyat aceh pasca perdamaian apa yang telah ditentukan dalam UUPA.

Menurut Akib dan Tarigan (2008) perspektif politik dan adiministratif menurut pernyataan Grindle adanya kesamaan elemen untuk mencapai tujuan kebijakan yang akan dibuat melalui faze pengambilan keputusan dalam model linear implementasi kebijakan. Dalam kajian ini akan disesuaikan dengan proses implementasi peranan DPRD yang dibincangkan adalah berkisar kepada keperluan-keperluan dalam teori tersebut. Perbincangan yang cuba dibuat dalam pelaksanaan kebijakan ialah tiga (3) elemen antara iaitu, pertama; kewenangan, kepentingan para eksekutif dan pihak legislatif dan masyarakat dalam strategi yang terlibat dalam kebijakan perancangan perundang-undangan. Dalam hal ini juga keterkaitan kedua; institusi dan ciri-ciri rejim yang terjadi pasca pengambilan keputusan kuasa legislatif dan eksekutif. Dan ketiga; Keberadaan peraturan perundang-undangan yang telah ditetapkan dan dilaksanakan secara komprehensif.

\section{METODE PENELITIAN}

Metodologi yang digunakan berbentuk tinjauan pendekatan metode kualitatif dengan analisis berasaskan deskriptif. Kajian kualitatif dalam Bogdan dan Taylor (1975), mentakrifkan sebagai prosedur penelitian yang menjadi data deskriptif, iaitu informasi dalam bentuk tulisan, perkataan dan pengamatan yang dihasilkan oleh peneliti sendiri. Teknik pengumpulan data dengan wawancara dan observes dengan menentukan key informan untuk mendapatkan informasi yang berkaitan dalam kajian ini. 


\section{HASIL DAN PEMBAHASAN}

UUPA Secara fundamental harus dilaksanakan secara tidak terpisah iaitu, fungsi politik dan fungsi administrasi. (Widodo, 2007 :15). Fungsi politik pemerintah berkaitan dengan pembuatan kebijakan (public policy making) atau pernyataan apa yang menjadi keinginan pemerintah. Sedangkan fungsi administrasi berkaitan dengan pelaksanaan kebijakan yang berkaitan tentang undang-undang sebagai nota kesepahaman ini. Maka Pelaksanaan UUPA belum optimal sebab aturan ini sebagai aturan yang normatif yang mengikat dapat dijelaskan dalam tahapan sebagai berikut:

\section{A. Kewenangan Dan Kepentingan Kebijakan Pemerintah}

Pelaksanaan nya implementasi kebijakan ini dlam kedudukan di wilayah autonomi khusus yang dijadikan sebagai pengambilan keputusan. Tahapan proses pelaksanaan adanya elemen penting yang harus diperhatikan dari perspektif ini adalah kewenagan dan kepentingan para eksekutif dan pihak legislatif dan masyarakat dalam strategi yang terlibat dalam kebijakan perancangan perundang-undangan dalam realisasi dari perundangan UUPA. Institusi dan ciriciri rejim yang terjadi pasca pengambilan keputusan kewenangan legislatif dan eksekutif, maka harus dapat mengendalikan permasalahan disesuaikan dengan kaedah yang berlaku. Sebab adanya dualisme kebijakan hukum dari peraturan ini, dalam menjalankan peraturan yang khusus harus mengikuti peraturan yang umum.

\section{B. Pengambilan Keputusan Dalam Implemantasi Kebijakan}

Pelaksanaan kebijakan dari UUPA yang telah di realisasi oleh pemerintah aceh menjadi tarik ulur bagi pemerintah pusat belum maksimal secara fungsi politik dan administratif dalam menwujudkan kepentingan publik. Maka dengan demikian pengambilan keputusan oleh pemerintah pusat kepada pemerintah aceh menjadi kontradiksi dari sejumlah point dalam kedudukan UUPA yang tidak dapat direalisasikan dengan penyataan dan klarifikasi jabawan tidak dapat diindentifikasi dengan jelas.

\section{Pelaksanaan Kebijakan Secara Komprehensif}

Peraturan perundang-undangan yang telah ditetapkan harus dilaksanakan dengan pematuhan yang responsif agar dapat mewujudkan kesejahteraan bagi masyarakat pasca konflik. Sebagai pencapaian matlamat pelaksanaan UUPA sangat menentukan kapasitas kelembagaan legislatif dan eksekutif dalam menjalankan peranan fungsinya dengan baik.

\section{SIMPULAN}

Perkembangan UUPA belum optimal dalam pelaksanaan, hal ini menunjukkan daripada kelemahan dalam pelaksanaan kebijakan pemerintah daerah aceh dapat dilihat dari segi adiministratif dan politik yang telah dilakukan. Kerana kedua fungsi daripada implementasi kebijakan ini akan dapat mempengaruhi output dan outcome dari matlamat yang telah ditetapkan dalam UUPA. Namun dalam mencapai dengan matlamat memerlukan strategi khusus dan sangat menentukan kapasiti lembaga legislatif DPRA/DPRD dalam menjalankan peranan dan fungsinya yang lebih accountable dalam mewujudkan aspirasi masyarakat demi untuk berlangsung perdamaian Aceh yang bermaruah. Maka sebagai cadangan lanjutan dalam kajian ialah peranan DPRA dalam implementasi UUPA di Aceh.

\section{REFERENSI}

Alfian. (2005), Wajah Aceh dalam lintasan sejarah. Yogyakarta. Gajah mada. University Press.

Akib at all. (2002), Artikulasi Konsep Implementasi Perspektif Model dan Criteria Pengukuran nya, Journal Public Policy, Vol (2) No (2) P. 8

Asra. (2010), Pembahagian Kewenangan Pusat-Daerah dalam UU-PA Nomor 11 Tahun 2006. Jurnal, Vol (2). No(1) P.6 
Amrizal. et all. (2007), Proses Pembentukan Undang-undang Pemerintahan Aceh (UU-PA), Jurnal Hukum Republika, Vol (16). No (2) P.4-5

Chaidar. Al. (1999), Gerakan Aceh Merdeka : Jihat Rakyat Aceh menuju Negara Islam. Jakarta : Madani Press

Edwar III, George C. (Edited) (1984), Public Policy Implementation. Jai Press Lns. Londonengland

Hamid. A. (2006), Jalan Damai Nenggroe Endatu : Catatan Seorang Wakil Rakyat Aceh. Jakarta . Secara Bebas

Rahmawati, et al. (2007), Persepsi Local dan Prospek Implementasi UU-PA : Aspek Kuasa Pemerintah Daerah dan Keuangan Daerah. Jurnal Politik .LIPI

Richard. (1996), Indonesia : The Rise of Capital Syney : Alien dan Unwir

Sautma. HK. (2008), Dampak Pembalakan Autonomi Khusus di Nanggroe Aceh Darussalam.jurnal, Vol(14) No (3).P. 1-4

Sholikin. M. (2006), UU-PA : Jalan Menuju Perdamaian dan Pemerkayaan Aceh. Jurnal, Vol (12). No (3), P.4

Sulaiman. M (2000), Aceh Merdeka : Ideologi Kepemimpinan dan Gerakan. Jakarta : Pustaka Al Kautsar

Trijono (2009), Pembangunan Perdamaian Pasca-Konflik di Indonesia : Kaitan Perdamaian. Pembangunan dan Demokrasi dalam Pengembangan Perlembagaan Pasca-Konflik. Jurnal. Vol. (130.No (1) P.18 